\title{
Oil removal from industrial wastewater using flotation in a mechanically agitated flotation cell
}

\author{
MLS Welz, N Baloyi and DA Deglon* \\ Department of Chemical Engineering, University of Cape Town, Rondebosch 7701, Cape Town, South Africa
}

\begin{abstract}
This paper investigates the flotation of oil from wastewater in a laboratory-scale mechanically agitated flotation cell. Mechanical flotation cells are used commercially for oil flotation but, to the authors' best knowledge, there are no studies on their flotation performance in the literature. Some researchers have suggested that mechanically agitated systems are inappropriate for oil flotation as the high shear rates may break up the fragile organic flocs. The chemical pretreatment operating factors of $\mathrm{pH}$ and type of acid adjustor, coagulant type and dosage and flocculant dosage were firstly investigated. When using $\mathrm{H}_{3} \mathrm{PO}_{4}$ for $\mathrm{pH}$ adjustment, a preferential $\mathrm{pH}$ of 5.5 was identified. When using $\mathrm{H}_{2} \mathrm{SO}_{4}$, a pH of 5.5 was not optimal. The acid type was subsequently the determining factor. $\mathrm{Al}_{2}\left(\mathrm{SO}_{4}\right)_{3}$ was a more effective coagulating agent than lime, based on coagulant and flocculant dosages required $\left(0.5 \mathrm{mg} / \ell\right.$ when using $\mathrm{Al}_{2}\left(\mathrm{SO}_{4}\right)_{3}$ and $1.5 \mathrm{mg} / \ell$ when using lime). The flotation cell operating factors of aeration rate and impeller speed were subsequently investigated. Oil removal rates were found to increase at higher levels of aeration and agitation. This suggests that oil flotation is both possible and beneficial in high-shear turbulent environments. However, residual oil concentrations could not be reduced to below 50 to $100 \mathrm{mg} / \ell$ which is higher than the desired target of $50 \mathrm{mg} / \ell$.
\end{abstract}

Keywords: oil flotation; wastewater, mechanical flotation cell

\author{
List of abbreviations \\ COD chemical oxygen demand \\ EFC electrochemical flotation cell \\ IAF induced air flotation \\ DAF dissolved air flotation \\ MFC mechanical flotation cell
}

\section{Introduction}

The effluent treatment area at FFS Refiners (Pty) Ltd in South Africa, processes oil-contaminated water for release into municipal sewers. The company aims to reduce their residual oil content to below $50 \mathrm{mg} / \ell$ for downstream removal of chloride ions and subsequent reduction in COD. The oil is derived from a variety of sources, e.g. refinery recycle streams, bilge water, light industries and rain water runoff. The exact oily water and surfactant composition is unknown due to raw material variations. Initially a DAF cell was used, as is common practice in effluent oil flotation, but this was replaced by an IAF cell due to capacity constraints on the DAF unit. The IAF attains residual oil contents in the vicinity of $200 \mathrm{mg} / \ell$ which is higher than the desired specifications.

MFCs are widely used in the minerals industry and offer the advantages of large capacities, high aeration rates and vigorously turbulent particle/droplet-bubble contacting. MFCs are used commercially for oil flotation (e.g. Wemco Depurator) but, to the authors' best knowledge, there are no literature studies on their flotation performance. Some researchers suggest that the

\footnotetext{
To whom all correspondence should be addressed.

面 +27 21 650-2980; fax: +27 21 650-5501;

e-mail: David.Deglon@uct.ac.za

Received 20 June 2006; accepted in revised form 14 May 2007.
}

high shear rates may break up the fragile organic flocs (Jameson, 1999 and Rubio et al., 2002). However, MFCs have been used in experimental studies on de-inking flotation and agitation has been found to improve the rate of flotation of ink droplets (Saint Amand, 1999). In addition, there is a trend towards increased levels of turbulence in DAF designs (Kiuru, 2001) as well as in applications of ultra-flocculation and turbulent micro-flotation to wastewater purification (Rulyvov, 1998). The bubble-droplet contacting efficiency due to inception increases with increasing turbulence (Nguyen et al., 2004).

The aim of this paper is to investigate the flotation of oil from wastewater in a laboratory-scale mechanical flotation cell. The paper first explores the effects of chemical factors ( $\mathrm{pH}$, coagulant, flocculant) on flotation performance and then investigates the effects of cell operational variables (air flow rate, impeller speed) under optimal chemical conditions.

\section{Background}

\section{Oil-water separation techniques}

Oil can be present in free, dispersed, emulsified or a soluble form up to $1000 \mathrm{mg} / \ell$. Free oil is non-dispersed and floats on the surface or coats equipment. The oily layers can be skimmed off. Non-emulsified dispersed oil can be removed by gravity separation, e.g. hydrocyclones, gravity filters or sedimentation (Da Rosa et al., 2005). Filters are generally avoided due to the high-pressure drop, although recent studies on oil removal by microfiltration/ultrafiltration have proven successful (Schoeman and Novhe, 2007). Settling tanks are popular on oilfields due to ease in management, steady operation and lower cost (Deng et al., 2004). If the oil droplets are small, the separation efficiency is accelerated through the addition of chemicals to the settling tanks to increase oil droplet size (Hamza et al., 1995). 
If surfactants are present, the oil may be emulsified. Surfactant molecules adsorb at fluid interfaces and modify interfacial properties by lowering the surface or interfacial tension (Moosai et al., 2003). Adsorbed surfactants may become charged due to the loss of a molecular group. Oil droplets are prevented from coalescence by electrostatic repulsive forces between charged oil surfaces. Emulsions can be kinetically or thermodynamically stabilised. Oil separation by means of gravity alone is difficult in either (Zouboulis et al., 2000). The standard method of treatment is chemical de-emulsification followed by gravity settling. This is expensive, as water from the chemical treatment needs additional purification (Mostefa et al., 2004). Flotation is an alternative as it has high efficiency as well as low operating costs and residence times, reducing the space requirements. Finely suspended droplets are separated from the emulsion by attachment to rising bubbles. The separation driving force is the increased difference in buoyancy of an attached oil droplet (Rubio et al., 2002). For efficient flotation, chemical pretreatment is required to increase the oil droplet size (Al-Shamrani et al., 2002), to at least $60 \mu \mathrm{m}$ (Moosai et al., 2003). An increased oil droplet size increases the rate of collection by air bubbles. Soluble oil requires the use of bioremediation or ion-exchange technology.

\section{Chemical pretreatment}

Chemical pretreatment improves separation efficiency by either a charge or size mechanism. A charge mechanism modifies the surface charge of the oil droplet while a size mechanism increases the size of the oil droplets such that there is a higher probability of collision between the oil droplet and the air bubble. Chemical pretreatment can be represented by a stable solution at a specific $\mathrm{pH}$, followed by coagulation and flocculation. Although the overall coagulation and flocculation mechanism lowers the energy barrier between oil droplets and air bubbles, the increase in droplet size, improving the probability of collision between the oil droplets and air bubbles, may be the determining factor (Gray et al., 1997). The overall effectiveness is determined by coagulating agent and dosage, solution $\mathrm{pH}$ and ionic strength, and nature of the organic compounds (Stephenson et al., 1995).

Coagulation: Oil droplets are negatively charged due to charged surfactants or adsorption of hydroxyl ions (Al-Shamrani et al., 2002 and Marinova et al., 1995). Repulsive electrostatic forces prevent coalescence. Introducing an opposite charge modifies the negative charge, encouraging oil droplets to coagulate and assisting in the attachment of coagulated oil droplets to the negative air bubbles (Moosai et al., 2003). Air bubbles in water are considered to have a negative surface charge due to their negative zeta potential. When using metal coagulants, $\mathrm{pH}$ is crucial as it influences the nature of polymeric species formed upon dissolution of the metal coagulant in water (Licsko, 1975). Previously lime has been used as a coagulant/precipitating agent but disadvantages include an increase sample $\mathrm{pH}$ and hardness, low COD removal capacity, and excessive sludge (Tasti et al., 2003). Aluminium salts are effective coagulating agents and are widely used in wastewater treatment (Al-Shamrani et al., 2002 and Stephenson et al., 1995). When added to water, $\mathrm{A} 1^{3+}$ hydrates and reacts to form monomers, polymers and solid precipitates. These hydrophobic polymers have a large surface area, an amorphous structure and a positive charge. This allows for adsorption onto negative oil surfaces, rendering them insoluble. Charge neutralisation leads to colloid destabilisation. $\mathrm{Al}_{2}\left(\mathrm{SO}_{4}\right)_{3}$ use is questioned due to cost and residual aluminium and sulphate ions in treated water (Licsko, 1975 and Stephenson et al., 1995).

Flocculation: A polymer forms larger stabilised hydrophobic flocs through bridging and/or electrostatic mechanisms. Bridging, the dominant mechanism, occurs when a polymer is adsorbed onto the surface of two or more droplets, forming a link. Electrostatic patching involves polymers lying flat on the droplet surface, with patches of opposite charge on different droplets attracting each other. These mechanisms overlap if the initial adsorption of the polymer during bridging arises from electrostatic attraction (Gray et al., 1997). Flocculation depends on type, molecular weight and ionisation degree of flocculant, composition and size of oil droplets, $\mathrm{pH}$ and chemical composition of solution (Sworska et al., 2000).

Flotation techniques: Table 1 presents a brief summary of DAF, IAF and mechanical flotation cells. DAF is most commonly used for removing oil from industrial wastewater. Oily droplets larger than $40 \mu \mathrm{m}$ are removed (Zouboulis et al., 2000). DAF is effective in combination with chemical pretreatment, as recoveries over $99 \%$ have been reported (Al-Shamrani et al., 2002). DAF is advantageous if hydrophilic materials need to be removed. The small bubbles may become physically trapped or nucleate within the flocs (Jameson, 1999). Disadvantages involve the small bubble sizes. They have a low hydraulic loading and low hold-up, which limits the cell effectiveness at high throughput. Variations, which try to improve on the DAF, exhibit a general trend towards more turbulence (Da Rosa et al., 2005 and Rubio et al., 2002). IAF has a number of advantages over DAF. The retention times are lower, usually less than 5 minutes, and the larger bubbles allow for more compact flotation systems provided chemical pretreatment is optimised. IAF can have airflow rates of $100 \%$ of the water stream whereas the DAF airflow can be as low as 5.6\% (Jameson, 1999). Mechanically agitated flotation cells are commonly used in the mineral industry with tank sizes up to $250 \mathrm{~m}^{3}$ (Deglon, 2005). They offer the advantages of large capacities, high aeration rates and vigorously turbulent particle/droplet-bubble contacting. Mechanically agitated flotation cells are used commercially for oil flotation but, to the authors' knowledge, there are no published studies on their flotation performance. Some researchers suggest that the high shear rates may break up the fragile organic flocs. However, as discussed in the introductory section agitation/turbulence has been found to improve particle/droplet-bubble contacting.

\section{Experimental}

\section{Materials}

Wastewater containing approximately $2000 \mathrm{mg} / \ell$ oil was taken from FFS. Oil was in free and emulsified form. No attempt was made to break the emulsion in the experiments. The average $\mathrm{pH}$ was 6.6. The surfactant was unknown although soap derivatives were most likely. Table 2 presents typical wastewater composition data after flotation and indicates that the residual oil concentrations are above the desired $50 \mathrm{mg} / \ell$. The average residual oil concentration for 2004 was $193 \mathrm{mg} / \ell$. A Mastersizer S Malvern was used for droplet size distribution analysis. Figure 1 shows the laboratory-scale mechanical flotation cell used in the study. It consists of a $3 \ell$ tank with a variable speed turbine ( 0 to $1600 \mathrm{r} / \mathrm{min}$ ) and air inlet pipe ( 0 to $10 \mathrm{l} / \mathrm{min}$ ) in the impeller region. A HACH 2000 turbidimeter with the highest sensitivity of $0.1 \mathrm{NTU}$ measured 


\begin{tabular}{|l|l|c|c|l|}
\hline \multicolumn{5}{|c|}{ Comparison of flotation techniques } \\
\hline & Method of bubble generation & Bubble size & $\begin{array}{c}\text { Relative energy required } \\
\text { to generate bubble surface } \\
\text { area }\left(\mathbf{W} / \mathbf{m}^{2} / \mathbf{s}\right)\end{array}$ & $\begin{array}{l}\text { Hydrodynamic } \\
\text { conditions }\end{array}$ \\
\hline DAF & $\begin{array}{l}\text { Pressurised recycle of } 20-50 \% \text { of clarified } \\
\text { effluent mixed with feed }\end{array}$ & $30-90 \mu \mathrm{m}$ & High & Quiescent \\
\hline IAF & Aerators & $>1000 \mu \mathrm{m}$ & Medium & $\begin{array}{l}\text { Quiescent-moderate } \\
\text { turbulence }\end{array}$ \\
\hline EFC & $\begin{array}{l}\text { Electrolysis of conducting solutions with gas } \\
\text { producing electrodes }\end{array}$ & $<100 \mu \mathrm{m}$ & High & Quiescent \\
\hline MFC & Forced mechanical dispersion & $>1000 \mu \mathrm{m}$ & Low & Turbulent \\
\hline
\end{tabular}

\begin{tabular}{|l|c|c|c|c|c|}
\hline \multicolumn{5}{|c|}{ TABLE 2 } \\
\hline & $\begin{array}{c}\text { Jan- } \\
\mathbf{0 4}\end{array}$ & $\begin{array}{c}\text { Jun- } \\
\mathbf{0 4}\end{array}$ & $\begin{array}{c}\text { Sep- } \\
\mathbf{0 4}\end{array}$ & $\begin{array}{c}\text { Dec- } \\
\mathbf{0 4}\end{array}$ & $\begin{array}{c}\text { Average- } \\
\mathbf{0 4}\end{array}$ \\
\hline COD (ppm) & 4797 & 4920 & 4590 & 9130 & 5859 \\
\hline Oil (ppm) & 211 & 134 & 50 & 147 & 136 \\
\hline $\begin{array}{l}\text { Dissolved solids at } \\
180^{\circ} \mathrm{C}(\mathrm{ppm})\end{array}$ & 7078 & 5750 & 9860 & 6220 & 7227 \\
\hline Chloride ions (ppm) & 1925 & 1540 & 3400 & 1040 & 1976 \\
\hline
\end{tabular}

* Taken from manufacturer

turbidity. $\mathrm{H}_{3} \mathrm{PO}_{4}$ and $\mathrm{H}_{2} \mathrm{SO}_{4}$ were used to acidify the wastewater. Petroleum ether was used for solvent extraction. A 3.13\% $(\mathrm{w} / \mathrm{w})$ solution of $\mathrm{Ca}(\mathrm{OH})_{2}$ or $\mathrm{Al}_{2}\left(\mathrm{SO}_{4}\right)_{3} 16 \mathrm{H}_{2} \mathrm{O}$ were used as coagulating agents. Aged liquid anionic polyacrylamide was used as the flocculant.

\section{Methods}

Characterising the feed: The feed required characterisation to ensure experimental homogeneity. The droplet size distributions across all chemical stages were below $20 \mu \mathrm{m}$, indicating ineffective size increases. The feedstock was proven to be homogeneous and have a constant size distribution through settling tests at constant oil concentrations, with turbidity as a response. The droplet size distribution was constant between chemical stages due to $2 \mathrm{~min}$ of agitation at $400 \mathrm{r} / \mathrm{min}$ after each chemical addition.

Calibration: Residual oil concentrations in the pulp were determined using calibration curves at varying impeller speeds. The solution turbidity was calibrated against the total oils and grease content, at constant droplet size distributions. The total oil and grease content was analytically assessed using the South African Bureau of Standards Method 1051. The calibrated relationship was linear with a correlation coefficient of 0.98 . Random analytical tests were performed to assess the accuracy of the calibration curve.

Flotation: After each chemical addition to the sample in the cell, agitation occurred for $2 \mathrm{~min}$ at $400 \mathrm{r} / \mathrm{min}$. Air was subsequently induced at $4 \mathrm{l} / \mathrm{min}$. Samples were drawn out of the supernatant fluid in the cell using a syringe at recorded time intervals. They were immediately analyzed using the turbidimeter. The experimental error was determined to have a coefficient of variation (relative precision) of $7 \%$.

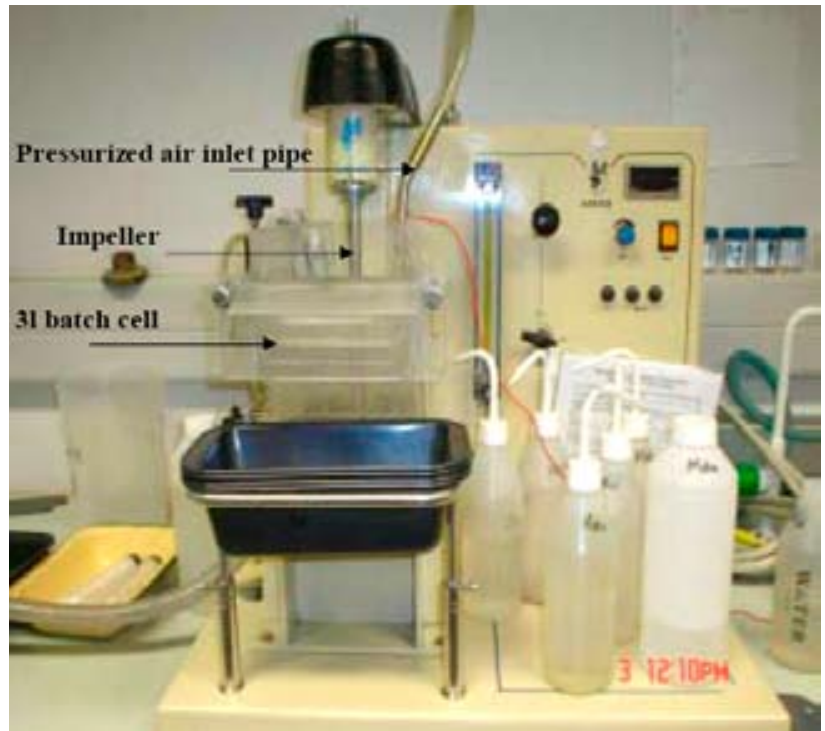

Figure 1

Schematic of the mechanical flotation cell

\section{Experimental programme}

Table 3 presents the conditions used for each investigation. The chemical reagents and conditions $\mathrm{H}_{3} \mathrm{PO}_{4},(\mathrm{pH}$ of 5.5$), 600 \mathrm{mg} / \ell$ $\mathrm{Ca}(\mathrm{OH})_{2}$ and $0.75 \mathrm{mg} / \ell$ flocculant, are plant standards. $\mathrm{H}_{2} \mathrm{SO}_{4}$ and $\mathrm{Al}_{2}\left(\mathrm{SO}_{4}\right)_{3}$ are standard alternatives for $\mathrm{pH}$ adjustment and coagulation. The lowest limit for effective gas dispersion was $900 \mathrm{r} / \mathrm{min}$, and the upper limit for minimal water recovery was 1 $100 \mathrm{r} / \mathrm{min} .6 \mathrm{l} / \mathrm{min}$ is the upper aeration limit due to water recoveries which were considered excessive as they exceeded $30 \%$.

\section{Results}

\section{Chemical pretreatment}

Table 4 presents the chemical pretreatment investigation results.

Effect of pH: A pH of 5 to 5.5 was optimal when using $\mathrm{H}_{3} \mathrm{PO}_{4}$ as the $\mathrm{pH}$ adjustor. The acid type was the determining factor, as evidenced by the poorer recovery at the same $\mathrm{pH}$ of 5.5 when using $\mathrm{H}_{2} \mathrm{SO}_{4}$ instead of $\mathrm{H}_{3} \mathrm{PO}_{4}$. The froth quantity and quality was superior when using $\mathrm{H}_{3} \mathrm{PO}_{4}$ compared to $\mathrm{H}_{2} \mathrm{SO}_{4}$.

Effect of coagulant type and dosage: When using lime, discontinuities range from 170 to $300 \mathrm{mg} / \ell$. The lowest dosage is 


\begin{tabular}{|l|c|c|c|c|c|c|c|}
\hline \multicolumn{7}{|c|}{ TABLE 3 } \\
\hline Variable & $\begin{array}{c}\mathbf{p H} \\
\text { adjustor }\end{array}$ & $\mathbf{p H}$ & $\begin{array}{c}\text { Coagulant } \\
\text { type }\end{array}$ & $\begin{array}{c}\text { Coagulant } \\
\text { dosage (ppm) }\end{array}$ & $\begin{array}{c}\text { Flocculant } \\
\text { dosage (ppm) }\end{array}$ & $\begin{array}{c}\text { Airflow rate } \\
\text { (e/min) }\end{array}$ & $\begin{array}{c}\text { Impeller } \\
\text { speed (r/min) }\end{array}$ \\
\hline pH & $\mathrm{H}_{3} \mathrm{PO}_{4}$ & $5-6.8$ & $\mathrm{Ca}(\mathrm{OH})_{2}$ & $\begin{array}{c}600 \\
\text { (plant -based) }\end{array}$ & - & - & 400 \\
\hline & $\mathrm{H}_{2} \mathrm{SO}_{4}$ & 5.5 & $\mathrm{Ca}(\mathrm{OH})_{2}$ & $\begin{array}{c}600 \\
\text { (plant -based) }\end{array}$ & - & - & 400 \\
\hline Lime & $\mathrm{H}_{3} \mathrm{PO}_{4}$ & 5.5 & $\mathrm{Ca}(\mathrm{OH})_{2}$ & $80-340$ & - & 4 & 900 \\
\hline Alum & $\mathrm{H}_{3} \mathrm{PO}_{4}$ & 5.5 & $\mathrm{Al}\left(\mathrm{SO}_{4}\right)_{3}$ & $25-50$ & - & 4 & 900 \\
\hline Floc. & $\mathrm{H}_{3} \mathrm{PO}_{4}$ & 5.5 & $\mathrm{Ca}(\mathrm{OH})_{2}$ & 170 & $0.25-2.5$ & 4 & 900 \\
\hline & $\mathrm{H}_{3} \mathrm{PO}_{4}$ & 5.5 & $\mathrm{Al}(\mathrm{SO})_{3}$ & 50 & $0.25-2.5$ & 4 & 900 \\
\hline $\begin{array}{l}\text { Impeller } \\
\text { speed }\end{array}$ & $\mathrm{H}_{3} \mathrm{PO}_{4}$ & 5.5 & $\mathrm{Ca}(\mathrm{OH})_{2}$ & 170 & 1.5 & 4 & $900-1100$ \\
\hline Airflow & $\mathrm{H}_{3} \mathrm{PO}_{4}$ & 5.5 & $\mathrm{Ca}(\mathrm{OH})_{2}$ & 170 & 1.5 & $4-6$ & 900 \\
\hline
\end{tabular}

\begin{tabular}{|l|l|l|}
\hline \multicolumn{3}{|c|}{ pH and coagulant investigation results } \\
\hline $\mathbf{p H}$ & $\begin{array}{l}\text { Highest degree of } \\
\text { aggregation }\end{array}$ & $\mathbf{5 - 6}$ \\
\hline & Recovery after $400 \mathrm{~s}$ & Recovery after $1000 \mathrm{~s}$ \\
\hline $5\left(\mathrm{H}_{3} \mathrm{PO}_{4}\right)$ & $73 \%$ & $85 \%$ \\
\hline $5.5\left(\mathrm{H}_{3} \mathrm{PO}_{4}\right)$ & $74 \%$ & $85 \%$ \\
\hline $5.5\left(\mathrm{H}_{2} \mathrm{SO}_{4}\right)$ & $\mathbf{3 3 \%}$ & $\mathbf{4 1 \%}$ \\
\hline $6\left(\mathrm{H}_{3} \mathrm{PO}_{4}\right)$ & $35 \%$ & $37 \%$ \\
\hline $6.8(\mathrm{unadjusted})$ & $33 \%$ & $35 \%$ \\
\hline $\mathrm{Lime}$ & Discontinuity range & $170-300 \mathrm{ppm}$ \\
\hline & Recovery after $400 \mathrm{~s}$ & Recovery after $1000 \mathrm{~s}$ \\
\hline $80 \mathrm{mg} / \ell$ & $10 \%$ & $15 \%$ \\
\hline $170 \mathrm{mg} / \ell$ & $82 \%$ & $92 \%$ \\
\hline $340 \mathrm{mg} / \ell$ & $50 \%$ & $65 \%$ \\
\hline $\mathrm{Al} \mathrm{l}_{2}(\mathrm{SO})_{3}$ & Discontinuity point & $50 \mathrm{mg} / \ell$ \\
\hline & Recovery after $400 \mathrm{~s}$ & Recovery after $1000 \mathrm{~s}$ \\
\hline $25 \mathrm{mg} / \ell$ & $80 \%$ & $80 \%$ \\
\hline $50 \mathrm{mg} / \ell$ & $84 \%$ & $89 \%$ \\
\hline
\end{tabular}

preferred, with a recovery of $92 \%$ after $1000 \mathrm{~s}$. Outside of the range, separation efficiencies are significantly lower. $\mathrm{Al}_{2}\left(\mathrm{SO}_{4}\right)_{3}$ has a lower CCC of $50 \mathrm{mg} / \ell$, with similar recoveries to those at the lime CCC of $170 \mathrm{mg} / \ell$.

Effect of flocculant dosage: The recoveries achieved at different flocculant dosages are listed in Table 5. All recoveries ultimately exceeded $95 \%$, but after different time intervals. The fastest separations occurred at $1.5 \mathrm{mg} / \ell$ of flocculant with 170 $\mathrm{mg} / \ell$ lime, and $0.5 \mathrm{mg} / \ell$ flocculant with $50 \mathrm{mg} / \ell \mathrm{Al}_{2}\left(\mathrm{SO}_{4}\right)_{3}$.

\section{Mechanical flotation cell operation}

Effect of aeration rate: Figure 2 presents a comparison of separation efficiencies at various aeration rates. At the lowest air flow rate $(2 \mathrm{l} / \mathrm{min})$, the rate of oil removal is controlled by the stability of the froth. At the higher air flow rates there is an initial flat region. Increasing the aeration rate increases the rate of oil removal but both the curves at $4 \ell / \mathrm{min}$ and $6 \ell / \mathrm{min}$ asymptote towards similar values of 50 to $100 \mathrm{mg} / \ell$.

Effect of impeller speed: Figure 3 presents a comparison of separation efficiencies at $900 \mathrm{r} / \mathrm{min}$ and $1100 \mathrm{r} / \mathrm{min}$, corresponding to approximately a doubling of the power input. The rate of oil removal is significantly higher at the higher impeller speed

\begin{tabular}{|c|c|}
\hline \multicolumn{2}{|c|}{ TABLE 5 } \\
Flocculant investigation results \\
\hline Flocculant (ppm) & Recovery after 400 s \\
\hline 0.25 & $91 \%$ \\
\hline 0.5 & $72 \%$ \\
\hline 1 & $91 \%$ \\
\hline 1.5 & $94 \%$ \\
\hline 2.5 & $93 \%$ \\
\hline $0.5\left(50 \mathrm{mg} / \ell \mathrm{Al}_{2}\left(\mathrm{SO}_{4}\right)_{3}\right)$ & $97 \%$ \\
\hline
\end{tabular}

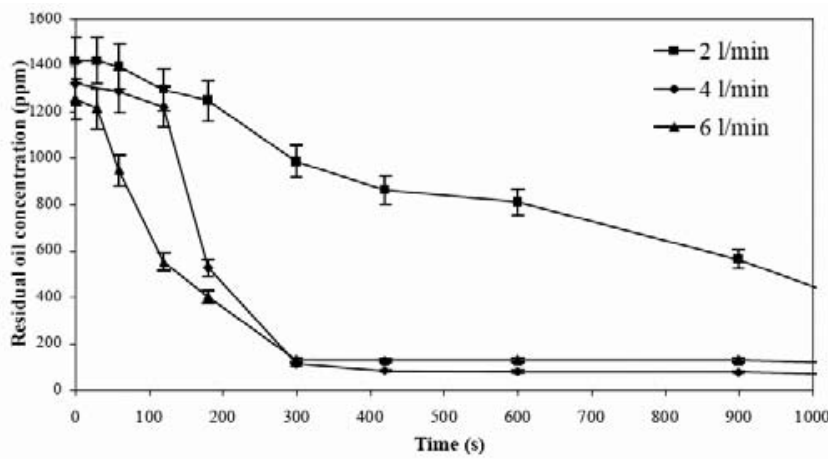

Figure 2

Oil content in emulsion as function of time for different airflow rates



Figure 3

Oil content in emulsion as function of time for different impeller speeds

but both curves again asymptote towards similar values of 50 to $100 \mathrm{mg} / \ell$. The $900 \mathrm{r} / \mathrm{min}$ response has a larger initial flat region due to a longer time for froth to build up. 


\section{Discussion}

\section{Chemical pretreatment}

Effect of pH: The superior froth may be due to increased surfactant liberation, which improves the froth. Proton addition could allow for a degree of coalescence due to the reduction in electrostatic repulsive forces between oil droplets. The relatively smaller ratio of surface area to volume liberates adsorbed surfactants. The probability of collection of an oil droplet is subsequently improved by two mechanisms:

- Probability of droplet-bubble collision is improved due to larger oil agglomerates

- Probability of droplet-bubble attachment is improved due to surfactant molecules stabilising the liquid film surrounding a bubble, inhibiting bubble coalescence.

$\mathrm{H}_{3} \mathrm{PO}_{4}$ may exhibit this behaviour and not $\mathrm{H}_{2} \mathrm{SO}_{4}$ due to a phosphate-lime interaction, similar to that noted by Adbel-Khalek, 2000. The compound formed $\left(\mathrm{CaHPO}_{4}\right)$ may preferentially adsorb onto the oil droplet, preventing and displacing surfactant molecules from doing likewise. An increase in $\mathrm{pH}$ decreases the separation efficiency. Under more alkaline conditions, the coagulating species become less positively charged, diminishing their attraction to the anionic oil droplets (Stephenson et al., 1995).

Effect of coagulant type and dosage: A discontinuity in physical properties as a function of coagulant concentration represents the critical coagulant concentration (CCC). Below the $\mathrm{CCC}$, insufficient counter-ions are available to neutralise the negatively charged system. Above the CCC, excess counter-ions are present, re-stabilising the system by reversing the charge. The lower $\mathrm{CCC}$ obtained when using $\mathrm{Al}_{2}\left(\mathrm{SO}_{4}\right)_{3}$ in comparison to lime, can be explained by the oversimplified Schulze-Hardy rule. While this rule fails when analyzing the activity of the similar ions $\mathrm{Fe}^{3+}$ and $\mathrm{Al}^{3+}$ due to the range of hydrolysis products formed, it is an adequate explanation for the simpler comparison between $\mathrm{Ca}^{2+}$ and $\mathrm{Al}^{3+}$ ions.

Effect of flocculant dosage: The relatively low flocculant dosages indicate that optimum flocculation occurs at less than complete droplet coverage (Sworska et al., 2000), ensuring sufficient unoccupied surface available for adsorption during collisions of the flocculant chains. The alternative use of $\mathrm{Al}_{2}\left(\mathrm{SO}_{4}\right)_{3}$ is justified as it requires a lower flocculant dosage. Economically, the use of $\mathrm{Al}_{2}\left(\mathrm{SO}_{4}\right)_{3}$ is further justified due to lower cost as well as lower dosage.

\section{Mechanical flotation cell operation}

Effect of aeration rate: The initial flat region found at higher air-flow rates is attributed to the time for froth to build-up. However, the subsequent rate of oil removal is controlled by dropletbubble contacting in the emulsion. The relationship between oil concentration and time was found to be $2^{\text {nd }}$ order. This indicates that the two sub-processes of droplet-droplet and droplet-bubble interactions may have equal importance as suggested by Gu et al., 1999.

Effect of impeller speed: The rate of oil removal is improved in the more turbulent system suggesting that agitation has a beneficial rather than disruptive effect on oil flotation. These findings show that oil from the FFS Refiners' effluent wastewater stream may be recovered in a mechanically agitated flotation cell and that rates of oil removal are increased at higher levels of aeration and agitation. This suggests that oil flotation is both possible and beneficial in a high-shear turbulent environment. Some researchers consider agitation to have a disruptive effect on oil flotation. However, the residual oil concentrations could not be reduced to below 50 to $100 \mathrm{mg} / \ell$ which is higher than the FFS target of $500 \mathrm{mg} / \ell$ and the concentrations of below $30 \mathrm{mg} / \ell$ achieved in some literature studies using DAF (Al-Shamrani et al., 2002).

\section{Conclusions}

The major conclusion from this study is that oil from the FFS Refiners effluent wastewater stream may be recovered in a mechanically agitated flotation cell and that rates of oil removal are increased at higher levels of aeration and agitation. This suggests that oil flotation is both possible and beneficial in a highshear turbulent environment which, to the authors' knowledge, has not been noted in the literature. However, the residual oil concentrations could not be reduced to below 50 to $100 \mathrm{mg} / \ell$. Detailed conclusions are:

\section{Flotation cell operation:}

- Rates of oil removal are increased at higher levels of aeration and agitation

- Flotation kinetics are $2^{\text {nd }}$ order indicating that a series of mechanical flotation cells is preferable to a single unit.

\section{Chemical optimisation:}

- Although an optimal $\mathrm{pH}$ of 5 to 5.5 exists, the acid type is the determining factor. The optimal results when using $\mathrm{H}_{3} \mathrm{PO}_{4}$ are proposed to be a result of surfactant liberation due to lime-phosphate interactions.

- The CCC for $\mathrm{Al}_{2}\left(\mathrm{SO}_{4}\right)_{3}(50 \mathrm{mg} / \ell)$ is lower than that of $\mathrm{Ca}(\mathrm{OH})_{2}(170 \mathrm{mg} / \ell)$. This can be explained through the Schulze-Hardy rule.

- The fastest kinetics occurred at $1.5 \mathrm{mg} / \ell$ of flocculant with $170 \mathrm{mg} / \ell$ lime, and $0.5 \mathrm{mg} / \ell$ flocculant with $50 \mathrm{mg} / \ell$ $\mathrm{Al}_{2}\left(\mathrm{SO}_{4}\right)_{3}$.

\section{Acknowledgements}

FFS Refiners (Pty) Ltd is gratefully acknowledged for their assistance and expertise without which this research would not have been possible

\section{References}

ABDEL-KHALEK NA (2000) Evaluation of flotation strategies for sedimentary phosphates with siliceous and carbonates gangues. Miner. Eng. 13 (7)789-793.

AL-SHAMRANI AA, JAMES A and XIAO H (2002) Separation of oil from water by dissolved air flotation. Colloids Surf. 209(1)15-26.

DA ROSA JJ and RUBIO J (2005) The FF (flocculation-flotation process). Miner. Eng. 18 (7) 701-707.

DEGLON D (2005) The effect of agitation on the flotation of platinum ores. Miner. Eng. 18 (2) 839-844.

DENG S, YU G, JIANG Z, ZHNANG R and TING YP (2004) Destabilization of oil droplets in produced water from ASP flooding. Colloids Surf. 252 (2-3) 113-119.

GRAY SR, HARBOUR PJ and DIXON DR (1997) Effect of polyelectrolyte charge density and molecular weight on the flotation of oil in water emulsions. Colloids Surf. 126 (2-3) 85-95.

GU X and CHIANG SH (1999) A novel flotation column for oily water cleanup. Sep. Purif. Technol. 16 (3) 193-203. 
HAMZA HA, STANONIK DJ and KESSICK MA (1995) Flocculation of lime-treated oil sands tailings. Fuel 75 (3) 280-284.

JAMESON GJ (1999) Hydrophobicity and floc density in induced-air flotation for water treatment. Colloids Surf. 151 (1-2) 269-281.

KIURU HJ (2001) Development of dissolved air flotation technology from the first generation to the newest (third) one (DAF in turbulent flow conditions). Water Sci. Technol. 43 (8) 1-7.

LICSKO I (1975) Micro processes in coagulation. Water Res. 10 (2) 143 147.

MARINOVA KG, ALARGOVA RG, DENKOV ND, VELEV OD, PETSEV DN and IVANOV IB (1995) Charging of oil-water interfaces due to spontaneous adsorption of hydroxyl ions. Langmuir 122045 2051.

MOOSAI R and DAWE RA (2003) Gas attachment of oil droplets for gas flotation for oily wastewater cleanup. Sep. Purif. Technol. 33 (3) 303-314.

MOSTEFA N and TIR N (2004) Coupling flocculation with electroflotation for waste oil/water emulsion treatment: Optimization of operating conditions. Desalination 161 (2) 115-121.

NGUYEN A and SCHULZE HJ (2004) Colloidal Science of Flotation, Surfactant Science Series (Vol. 118). Published by Marcel Dekker Inc, New York. Chapter 11. 209-254
RUBIO J, SOUZA ML and SMITH RW (2002) Overview of flotation as a wastewater treatment technique. Miner. Eng. 15 (3) 135-155.

RULYVOV NN (1998) Application of ultra-flocculation and turbulent microflotation to the removal of fine contaminants from water. $\mathrm{Col}$ loids Surf. A 151 283-291.

SAINT AMAND FJS (1999) Hydrodynamics of de-inking flotation. Int. J. Miner. Proc. 56 (1-4) 277-316.

SCHOEMAN JJ and NOVHE O (2007) Evaluation of microfiltration for the treatment of spent cutting-oil. Water SA 33 (2) 245-248.

STEPHENSON RJ and DUFF SJB (1995) Coagulation and precipitation of a mechanical pulping effluent - I. Removal of carbon, colour and turbidity. Water Res. 30 (4) 781-792.

SWORSKA A, LASKOWSKI JS and CYMERMAN G (2000) Flocculation of the Syncrude fine tailings Part 1. Effect of $\mathrm{pH}$, polymer dosage and $\mathrm{Mg}^{2+}$ and $\mathrm{Ca}^{2+}$ cations. Int. J. Miner. Proc. 60 (2) 143-152.

TASTI AA, ZOUBOULIS AI, MATIS KA and SAMARAS P (2003) Coagulation- flocculation pretreatment of sanitary landfill leachates. Chemosphere 53 (7) 737-744.

ZOUBOULIS, AI and AVRANAS, A (2000) Treatment of oil-in-water emulsions by coagulation and dissolved-air flotation. Colloids Surf. $172(1-2)$ 153-161. 